Citation: GONZÁLEZ GARCÍA, I; DEL VALLE GÁLVEZ, A; CALVO MARISCAL, L; TORREJÓN RODRÍGUEZ, J. D: «Documentación. I. Naciones Unidas - Gibraltar - Decisiones aprobadas por la Asamblea General de la ONU (2017-2019)», Cuadernos de Gibraltar-Gibraltar Reports, num. 4, 2020-2021.

\title{
I. NACIONES UNIDAS - GIBRALTAR - DECISIONES APROBADAS POR LA ASAMBLEA GENERAL DE LA ONU $(2017-2019)^{*}$
}

\author{
Inmaculada GONZÁLEZ GARCÍA**; Alejandro DEL VALLE GÁLVEZ; \\ Lorena CALVO MARISCAL; Juan Domingo TORREJÓN RODRÍGUEZ
}

\section{Documentación incluida en este apartado:}

DOCUMENTO 1. Decisión de la Asamblea General sobre la cuestión de Gibraltar, 3 de octubre de 2017.

DOCUMENTO 2. Decision of the General Assembly, Question of Gibraltar, 3 October 2017.

DOCUMENTO 3. Decisión de la Asamblea General sobre la cuestión de Gibraltar, 2 de noviembre de 2018.

DOCUMENTO 4. Decision of the General Assembly, Question of Gibraltar, 2 November 2018.

DOCUMENTO 5. Decisión de la Asamblea General sobre la cuestión de Gibraltar, 9 de octubre de 2019.

DOCUMENTO 6. Decision of the General Assembly, Question of Gibraltar, 9 October 2019.

\footnotetext{
* Las Resoluciones y Decisiones de la Asamblea General de Naciones Unidas sobre la cuestión de Gibraltar anteriores a 2017 pueden verse en la sección de Documentación de los números 1 (2015) y 2 (2017) de la Revista Cuadernos de Gibraltar / Gibraltar Reports, así como en la sección de documentación de los libros editados por A del Valle Gálvez, e I. González García: Gibraltar, 300 años, Cádiz, 2004, pp. 462-ss, y Gibraltar y el Foro tripartito de Diálogo, Dykinson Madrid 2009, pp. 510-ss.

** Esta Sección se enmarca en el Proyecto de Investigación financiado por la Fundación Pública Andaluza Centro de Estudios Andaluces (PRY205/19): «La incidencia del 'Brexit' en la cooperación transfronteriza entre Gibraltar-Campo de Gibraltar y Andalucía», coordinado por la Profesora Inmaculada González García. Período de vigencia, 2020-2022.
} 


\author{
Septuagésimo segundo período de sesiones \\ Comisión Política Especial y de Descolonización \\ (Cuarta Comisión) \\ Tema 62 del programa \\ Aplicación de la Declaración sobre la Concesión de \\ la Independencia a los Países y Pueblos Coloniales
}

Proyecto de decisión presentado por el Presidente

\title{
Cuestión de Gibraltar
} 2016:

La Asamblea General, recordando su decisión 71/521 de 6 de diciembre de

a) Insta a los Gobiernos de España y del Reino Unido de Gran Bretaña e Irlanda del Norte a que, escuchando los intereses y las aspiraciones de Gibraltar que sean legítimas conforme al derecho internacional, lleguen, en el espíritu de la Declaración de Bruselas de 27 de noviembre de 1984, a una solución definitiva de la cuestión de Gibraltar a la luz de las resoluciones pertinentes de la Asamblea General y los principios aplicables, y de conformidad con el espíritu de la carta de las Naciones Unidas;

b) Toma nota de la posición de España sobre esta cuestión, incluida su propuesta de comenzar nuevas discusiones sobre la base de la Declaración de Bruselas, y toma nota también de la presentación por parte de España de una propuesta de soberanía conjunta ante la Comisión Política Especial y de Descolonización el 4 de octubre de 2016;

c) Toma nota de la posición del Reino Unido sobre esta cuestión, es decir, el compromiso de nunca suscribir acuerdos según los cuales la población de Gibraltar quede bajo la soberanía de otro Estado en contra de sus deseos expresados de forma democrática y libre, ni de participar en un proceso de negociaciones de soberanía con el que Gibraltar no esté conforme;

d) Toma nota de la voluntad del Reino Unido de continuar con el Foro Trilateral de Diálogo;

e) Toma nota de la posición de España de que el Foro Trilateral de Diálogo ya no existe y debe ser sustituido por un nuevo mecanismo de cooperación local en el que estén representados los habitantes del Campo de Gibraltar y de Gibraltar;

f) Alienta al Reino Unido y a España a que trabajen de forma constructiva y receptiva con todas las partes relevantes y pertinentes, con el fin de encontrar soluciones comunes y avanzar en cuestiones de interés mutuo. 


\section{Seventy-second session \\ Special Political and Decolonization Committee \\ (Fourth Committee) \\ Agenda item 62 \\ Implementation of the Declaration on the Granting of \\ Independence to Colonial Countries and Peoples}

Draft decision submitted by the Chair

\section{Question of Gibraltar}

The General Assembly, recalling its decision 71/521 of 6 December 2016:

(a) Urges the Governments of Spain and the United Kingdom of Great Britain and Northern Ireland, while listening to the interests and aspirations of Gibraltar that are legitimate under international law, to reach, in the spirit of the Brussels Declaration of 27 November 1984, a definitive solution to the question of Gibraltar, in the light of the relevant resolutions of the General Assembly and applicable principles, and in the spirit of the Charter of the United Nations;

(b) Takes note of the position of Spain on this issue, including its proposal to start new discussions on the basis of the Brussels Declaration, and also takes note of Spain's presentation of a co-sovereignty offer before the Special Political and Decolonization Committee, on 4 October 2016;

(c) Takes note of the position of the United Kingdom on this issue, that is, the commitment never to enter into arrangements under which the people of Gibraltar would pass under the sovereignty of another State against their freely and democratically expressed wishes, nor enter into a process of sovereignty negotiations with which Gibraltar is not content;

(d) Takes note of the desire of the United Kingdom to continue with the trilateral Forum for Dialogue;

(e) Takes note of the position of Spain that the trilateral Forum for Dialogue does not exist any longer and should be replaced with a new mechanism for local cooperation in which the people of the Campo de Gibraltar and Gibraltar are represented;

(f) Encourages the United Kingdom and Spain to engage in a constructive and responsive manner, with all relevant and appropriate parties, in order to find common solutions and make progress on issues of mutual benefit. 
Tema 63 del orden del día

Aplicación de la Declaración sobre la Concesión de

la Independencia a los Países y Pueblos Coloniales

\section{Proyecto de decisión presentado por la Presidencia}

\section{Cuestión de Gibraltar}

La Asamblea General, recordando su decisión 72/520, de 7 de diciembre de 2017:

a) Insta a los Gobiernos de España y del Reino Unido de Gran Bretaña e Irlanda del Norte a que, escuchando los intereses y las aspiraciones de Gibraltar que sean legítimas conforme al derecho internacional, lleguen, en el espíritu de la Declaración de Bruselas de 27 de noviembre de 1984, a una solución definitiva de la cuestión de Gibraltar a la luz de las resoluciones pertinentes de la Asamblea General y los principios aplicables, y de conformidad con el espíritu de la Carta de las Naciones Unidas;

b) Toma nota de la voluntad del Reino Unido de continuar con el Foro trilateral de Diálogo;

c) Toma nota de la posición de España de que el Foro trilateral de Diálogo ya no existe y debe ser sustituido por un nuevo mecanismo de cooperación local en el que estén representados los habitantes del Campo de Gibraltar y de Gibraltar;

d) Acoge con beneplácito los esfuerzos hechos por todos para resolver problemas y avanzar en un espíritu de confianza y solidaridad, con el fin de encontrar soluciones comunes y progresar en áreas de interés mutuo hacia una relación basada en el diálogo y la cooperación. 
Seventy-third session

Special Political and Decolonization Committee

(Fourth Committee)

Agenda item 63

Implementation of the Declaration on the Granting of

Independence to Colonial Countries and Peoples

Draft decision submitted by the Chair

\section{Question of Gibraltar}

The General Assembly, recalling its decision 72/520 of 7 December 2017:

(a) Urges the Governments of Spain and the United Kingdom of Great Britain and Northern Ireland, while listening to the interests and aspirations of Gibraltar that are legitimate under international law, to reach, in the spirit of the Brussels Declaration of 27 November 1984, a definitive solution to the question of Gibraltar, in the light of the relevant resolutions of the General Assembly and applicable principles, and in the spirit of the Charter of the United Nations;

(b) Takes note of the desire of the United Kingdom to continue with the trilateral Forum for Dialogue;

(c) Takes note of the position of Spain that the trilateral Forum for Dialogue does not exist any longer and should be replaced with a new mechanism for local cooperation in which the people of the Campo de Gibraltar and Gibraltar are represented;

(d) Welcomes the efforts made by all to resolve problems and advance in a spirit of trust and solidarity, in order to find common solutions and move forward in areas of mutual interest towards a relationship based on dialogue and cooperation. 
Septuagésimo cuarto período de sesiones

Comisión Política Especial y de Descolonización

(Cuarta Comisión)

Tema 59 del programa

Aplicación de la Declaración sobre la Concesión de

la Independencia a los Países y Pueblos Coloniales

Proyecto de decisión presentado por la Presidencia

\section{Cuestión de Gibraltar}

La Asamblea General, recordando su decisión 73/519 de 7 de diciembre de 2018:

a) Insta a los Gobiernos de España y del Reino Unido de Gran Bretaña e Irlanda del Norte a que, escuchando los intereses y las aspiraciones de Gibraltar que sean legítimas conforme al derecho internacional, lleguen, en el espíritu de la Declaración de Bruselas de 27 de noviembre de 1984, a una solución definitiva de la cuestión de Gibraltar, a la luz de las resoluciones pertinentes de la Asamblea General y los principios aplicables, y de conformidad con el espíritu de la Carta de las Naciones Unidas;

b) Toma nota de la voluntad del Reino Unido de continuar con el Foro trilateral de Diálogo;

c) Toma nota de la posición de España de que el Foro trilateral de Diálogo ya no existe y debe ser sustituido por un nuevo mecanismo de cooperación local en el que estén representados los habitantes del Campo de Gibraltar y de Gibraltar;

d) Acoge con satisfacción los esfuerzos hechos por todos para resolver problemas y avanzar en un espíritu de confianza y solidaridad, con el fin de encontrar soluciones comunes y progresar en áreas de interés mutuo hacia una relación basada en el diálogo y la cooperación. 
Seventy-fourth session

Special Political and Decolonization Committee

(Fourth Committee)

Agenda item 59

Implementation of the Declaration on the Granting of

Independence to Colonial Countries and Peoples

Draft decision submitted by the Chair

\section{Question of Gibraltar}

The General Assembly, recalling its decision 73/519 of 7 December 2018:

(a) Urges the Governments of Spain and the United Kingdom of Great Britain and Northern Ireland, while listening to the interests and aspirations of Gibraltar that are legitimate under international law, to reach, in the spirit of the Brussels Declaration of 27 November 1984, a definitive solution to the question of Gibraltar, in the light of the relevant resolutions of the General Assembly and applicable principles, and in the spirit of the Charter of the United Nations;

(b) Takes note of the desire of the United Kingdom to continue with the trilateral Forum for Dialogue;

(c) Takes note of the position of Spain that the trilateral Forum for Dialogue does not exist any longer and should be replaced with a new mechanism for local cooperation in which the people of the Campo de Gibraltar and Gibraltar are represented;

(d) Welcomes the efforts made by all to resolve problems and advance in a spirit of trust and solidarity, in order to find common solutions and move forward in areas of mutual interest towards a relationship based on dialogue and cooperation. 


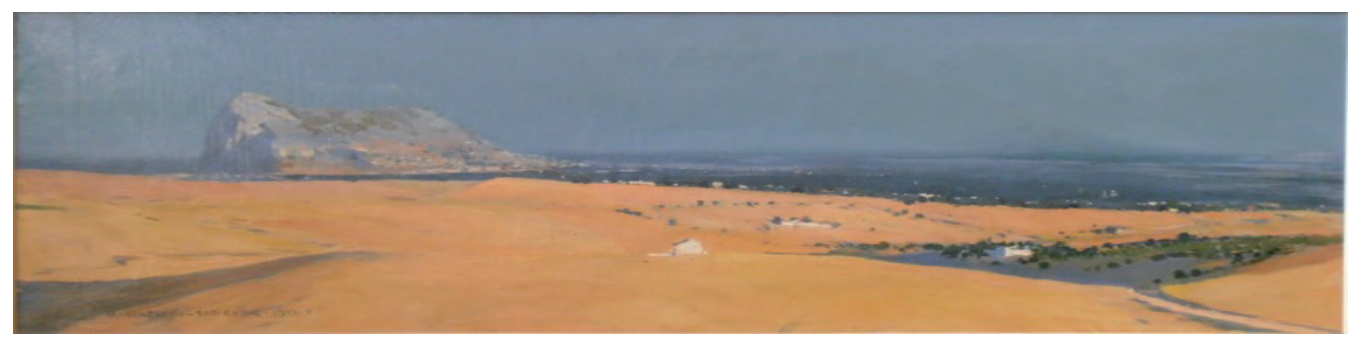

\section{Cuadernos de Gibraltar Gibraltar Reports}

\section{\#04 | 2020-2021}

Sumario

Table of Contents

\section{EDITORIAL}

Alejandro DEL VALLE GÁLVEZ; Inmaculada GONZÁLEZ GARCÍA, Gibraltar after the Brexit: Looking for a New and Imaginative Model of Cross-Border Cooperation in the EU Framework

\section{ESTUDIOS Y NOTAS}

Luis M. HINOJOSA MARTÍNEZ, Los movimientos de capital y los servicios financieros en las relaciones con Reino Unido y Gibraltar tras el Brexit: ¿Seguridad jurídica o ley de la selva?

Luis ROMERO BARTUMEUS, Las escalas de submarinos nucleares en Gibraltar y Rota, y los Planes de Emergencia Radiológica

Facundo D. RODRÍGUEZ, La cuestión de las Malvinas (Falklands) en el Cuarto Decenio Internacional para la Eliminación del Colonialismo

\section{ÁGORA}

Alejandro DEL VALLE GÁLVEZ, Creación de una AECT-Agrupación Europea de Cooperación Territorial- Campo de Gibraltar/Gibraltar (Guía breve sobre planteamiento, requisitos y procedimiento)

Alejandro GARCÍA HEREDIA, El Acuerdo Fiscal entre España y el Reino Unido en relación con Gibraltar

David CHEVASCO, Notes on Contemporary Bilingualism, Llanito and Language Policy in Gibraltar: a Study with a Present-day View of Linguistic Challenges

\section{DOCUMENTACIÓN}

Inmaculada GONZÁLEZ GARCÍA; Alejandro DEL VALLE GÁLVEZ; Lorena CALVO MARISCAL, Juan D. TORREJÓN RODRÍGUEZ:

Documentación I. Naciones Unidas - Gibraltar - Decisiones aprobadas por la Asamblea General de la ONU (2017-2019)

Documentación II. Brexit y Gibraltar - Tratado de Retirada, Protocolo, Tratado Fiscal y MOUs (2018-2020)

Documentación III. España, Brexit y Gibraltar. Declaraciones, Comunicados y Notas de Prensa (2018-2020)

Documentación IV. Andalucía, Brexit y Gibraltar (2018-2019)

Documentación V. Grupo Transfronterizo/Cross-Frontier Group, Memorándum de Entendimiento con el Gobierno de Gibraltar (2017) y Reglamento de Funcionamiento (2018)

Documentación VI. Principio de Acuerdo entre España y el Reino Unido sobre Gibraltar y sobre el Brexit, de 31.12.2020

Documentación VII. Mandato negociador para el Tratado entre el Reino Unido y la Unión Europea con respecto a Gibraltar, 5 de octubre de 2021

\section{LOS ARCHIVOS DE LUIS ROMERO BARTUMEUS}

La descolonización de Gibraltar, de CALVAR, J. - GUERITZ , E. J. - DEL CAMPO, S. - DAVIS H., Ed. Instituto de Cuestiones Internacionales, 1981, 110 páginas, por Luis ROMERO BARTUMEUS

Matar al Mensajero, Vivencias de un «Palomo» en Gibraltar, de TRIAY BOZZINO, J. J. - CASAUS BALAO, J. A., Ed. : Colecciones AUREA, 2000, 198 páginas, por Luis ROMERO BARTUMEUS

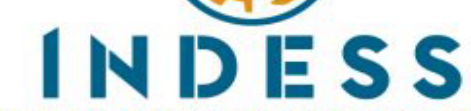

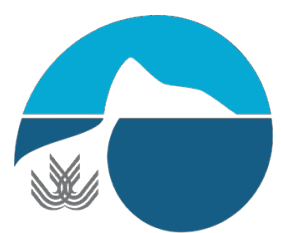

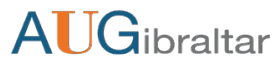

CÁTEDRA JEAN MONNET INMIGRACIÓN Y FRONTERAS DERECHO DE LA UNIÓN EUROPEA $\sim 2$

EDUCACIÓN DE LA UNIÓN EUROPEA

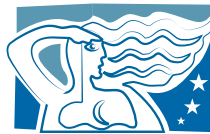

ESTUDIOS

INTERNACIONALES Y EUROPEOS

Centro de Estudios Internacionales y Europeos del Área del Estrecho 